\title{
Hereditary sensory and autonomic neuropathy in a male child: 'The other side of not feeling pain'
}

\author{
Nripen Gaur, ${ }^{1}$ Rachna Meel, ${ }^{2}$ Shahnaz Anjum, ${ }^{1}$ Pallavi Singh ${ }^{1}$
}

${ }^{1}$ Department of Ophthalmology, Dr. Rajendra Prasad Centre for Ophthalmic Sciences, AllMS, New Delhi, India

${ }^{2}$ Dr. Rajendra Prasad Centre for Ophthalmic Sciences, All India Institute of Medical Sciences, New Delhi, India

\section{Correspondence to}

Dr Rachna Meel,

dr.rachnameel@gmail.com

Accepted 23 August 2018

\section{DESCRIPTION}

A 1-year-old boy was brought to our outpatient department with complaints of whitish opacity in both eyes noticed 3 months ago. The mother also gave a history of self-mutilating behaviour in the child. There was a history of absence of crying during vaccination. There was no history of consanguinity and a similar disease in the family. The child was following light binocularly. On anterior segment examination, bilateral corneal scarring secondary to keratitis was seen (figure 1A). Corneal sensations were absent. An ocular ultrasonography was done for posterior segment evaluation, which revealed no abnormalities. There were signs of self-mutilation in the perioral area in form of damage to both upper and lower lips that caused as a result of repeated insults in form of tooth bite (figure 1B). Apart from this, similar injuries were present in fingers of hands (figure 1C) as well as toes. On neurological examination, the child had normal motor functions, and deep tendon reflexes were normal. No thickening of peripheral nerves was noted. However, there was no response to pain and temperature stimuli. Rest of the systemic examination was not remarkable. No abnormality was found on neuroimaging. The child was referred to the department of paediatrics where a clinical diagnosis of hereditary sensory and autonomic neuropathy (HSAN) was made. Nerve conduction
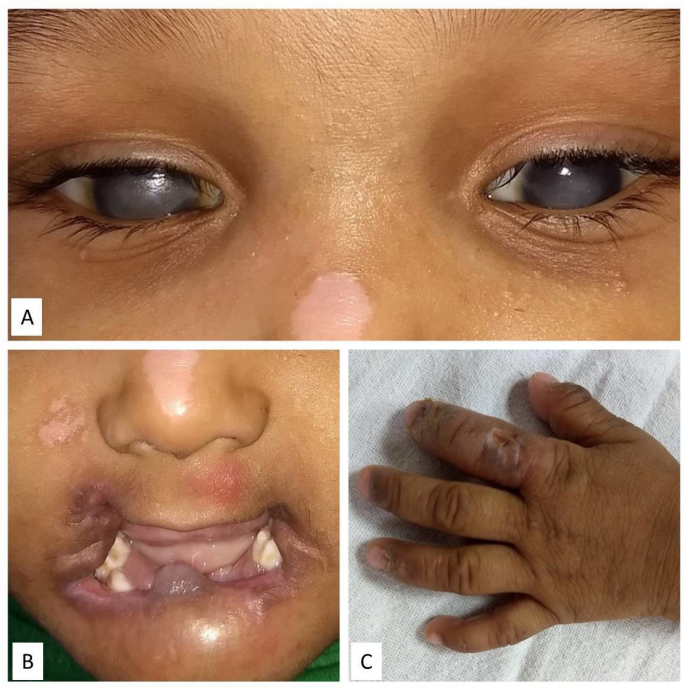

Figure 1 (A) Clinical photograph showing the bilateral corneal scarring and keratinisation. (B) This shows the destruction of lips caused by tooth bite along with dental attrition. (C) This shows self-mutilation sequelae in distal phalanges secondary to tooth bite.

\section{Learning points}

- Hereditary sensory and autonomic neuropathy must be kept as a differential for a child having insensitivity towards pain and temperature.

- Delay in diagnosis can be detrimental and can lead to severe injuries and visual complications.

study and sympathetic skin response tests showed absent sympathetic response from the skin of both hands and both feet. However, the electromyography study was normal. Gene sequencing test revealed the presence of homozygous mutation in the PRDM12 gene, which confirmed the diagnosis of HSAN type 8 (HSA-VIII). The child was referred to the department of cornea for considering visual rehabilitation in form of keratoplasty.

HSAN is a group of disorder that is characterised by inherited autonomic and sensory neurological defect. HSAN is further classified into eight types based on the genetic mutation and clinical characteristics. ${ }^{1}$ HSAN-VIII is caused by the homozygous mutations in the PRDM12 gene. This syndrome compromises of following features: insensitivity to pain and thermal stimuli, self-mutilation behaviour, altered sweat and tear formation, the absence of corneal reflexes and presence of repeated infections of the skin and bone. ${ }^{2}$ The patients having PRDM12 mutations lack pain sensations. ${ }^{3}$ Hence, these patients are subject to multiple injuries leading to recurrent skin infections and bone deformities. The lack of corneal sensations can lead to corneal neurotrophic ulcerations and subsequent scarring. Pain insensitivity can lead to oral mutilations like dental attrition, bite wounds, premature tooth loss and ulcerations. The most common sites for self-inflicted injuries involve oral mucosa and lips. The rare nature of this disease often leads to a delayed diagnosis and development of complications. The management involves use of lubricants to prevent corneal ulcers. Frequent and careful examination of limbs to look for any fresh injuries should be done.

Contributors NG, SA and PS contributed to diagnosis, workup, writing the manuscript and performing critical revision. RM is the overall responsible for the presentation, contributed to diagnosis and performed critical revision of the manuscript.

Funding The authors have not declared a specific grant for this research from any funding agency in the public, commercial or not-for-profit sectors.

Competing interests None declared.

Patient consent Parental/guardian consent obtained.

Provenance and peer review Not commissioned; externally peer reviewed. 


\section{REFERENCES}

1 Elhennawy K, Reda S, Finke C, et al. Oral manifestations, dental management, and a rare homozygous mutation of the PRDM12 gene in a boy with hereditary sensory and autonomic neuropathy type VIII: a case report and review of the literature. J Med Case Rep 2017;11:233.
2 Chen YC, Auer-Grumbach M, Matsukawa S, et al. Transcriptional regulator PRDM12 is essential for human pain perception. Nat Genet 2015;47:803-8.

3 Zhang S, Malik Sharif S, Chen YC, et al. Clinical features for diagnosis and management of patients with PRDM12 congenital insensitivity to pain. J Med Genet 2016;53:533-5.

Copyright 2018 BMJ Publishing Group. All rights reserved. For permission to reuse any of this content visit http://group.bmj.com/group/rights-licensing/permissions.

BMJ Case Report Fellows may re-use this article for personal use and teaching without any further permission.

Become a Fellow of BMJ Case Reports today and you can:

- Submit as many cases as you like

- Enjoy fast sympathetic peer review and rapid publication of accepted articles

- Access all the published articles

Re-use any of the published material for personal use and teaching without further permission

For information on Institutional Fellowships contact consortiasales@bmjgroup.com

Visit casereports.bmj.com for more articles like this and to become a Fellow 